\title{
A CRITICAL APPRAISAL OF THE DESIGN, CONSTRUCTION AND INFLUENCE OF THE UNITÉ D'HABITATION, MARSEILLES, FRANCE
}

\author{
Malcolm MILLAIS \\ Independent researcher \\ E-mail:malcolm.millais@sapo.pt
}

Received 4 April 2015; accepted 21 May 2015

\begin{abstract}
The Unité d'Habitation is a seventeen-storey apartment block built between 1947 and 1952 in Marseilles, France. Today the construction of such a building, in almost any part of the world, would hardly be newsworthy; however the construction of the Unité d'Habitation not only attracted global interest at the time, but it can also be seen as one of the most influential buildings of the twentieth century. This was for a number of reasons. The architect was Charles-Edouard Jeanneret-Gris who, better known as Le Corbusier for most of his adult life, was probably the most influential architect of the twentieth century. The building, in many ways, initiated the hegemony of Modern Movement architecture throughout the world. But, perhaps most importantly, it was seen by much of the architectural profession as a prototype for how people should be housed in the future - with consequential major social, environmental and urban impacts. This paper examines the background of the design and describes the construction in detail. It also comments critically on the building's suitability as a model for mass housing, revealing the extent of its various functional failings that have not, as far as the author is aware, previously been exposed.
\end{abstract}

Keywords: Unité d'Habitation, high-rise housing, Le Corbusier, functionality, modernism.

\section{Introduction}

This paper describes the design and construction of a seventeen-storey apartment building called the Unité d'Habitation that was built between 1947 and 1952 in the southern French city of Marseilles. The building was designed by the Swiss-French architect Le Corbusier who intended it to be a prototype for mass housing for the modern age, and can be seen as the culmination of his life's work. It had an enormous influence on the architectural profession, and was the catalyst for the widespread adoption of Modern Movement architecture after World War II.

The development of the design of the building is explained, together with the relevant influences. Finally, a critical assessment of the technical aspects of the building is presented, together with a commentary on its role as a model for mass housing.

\section{Charles-Edouard Jeanneret-Gris becomes the architect Le Corbusier}

Charles-Edouard was born on October $6^{\text {th }}, 1887$ in the Swiss watch-making town of La Chaux-de-Fonds.
After a rather chequered early career in his home town, he left for Paris in January 1917, where he was to establish himself as an avant-garde architect, with the new name of Le Corbusier.

In 1923 he published what was to become his bestknown book Vers Une Architecture. Although it can be seen as a manifesto for a new architecture, it was hardly easy to follow. In 1926, Le Corbusier published something that was easier to follow; it was called 'The Five Points of Architecture' (Almanach... 1926), which were:

1. Buildings should be raised up on columns - pilotis.

2. There should be no internal load-bearing walls allowing a planning freedom - plan libre (Curtis 1986: 42).

3. External walls should be non-load-bearing façade libre.

4. Windows should be in long strips - fenêtre en longeur.

5. The roof should be flat and used as a garden - toit jardin. 
These five points were used extensively by Le Corbusier and for that matter by many other architects, the results of which can be seen in hundreds of buildings world-wide.

\section{Le Corbusier and the housing problem}

The design of houses tends to be central to the work of many architects, and Le Corbusier was no different. But his interest became wider than just the design of houses for individual clients; he felt he should be able to solve 'the housing problem.' By this he meant that there should be a universal housing type that would be suitable for people who were to live in the new modern world. In his book, Vers une architecture, he suggests that a new architecture is needed for the 'modern man' and the 'modern woman', as he describes them (Le Corbusier 1927: 112).

His first attempt at mass housing was a proposal he made in 1914; it was called the Domino house. This was based on a six-columned, two-storey concrete structure that would form the basis of various housing arrangements. It was never built ${ }^{1}$. His next attempt was called the Citrohan house, a model of which was exhibited at the 1922 Salon d'Automne. Inspired by the flat-roofed, whitewashed houses of the Greek islands and the Café Mauroy $^{2}$, this flat-roofed house, raised up on columns, had a double-height living space with a sleeping area on a mezzanine.

During the 1920s Le Corbusier had three opportunities to provide housing that was more than just an individual house. At Pessac, near Bordeaux, he designed a small housing estate for the workers employed by Henri Frugès (Fig. 1), and in Paris he designed residential accommodation for Swiss students at the University of Paris, and a hostel for the Salvation Army.

\section{The origins of the Unité d'Habitation}

In 1929, Swiss businessman Edmond Wanner asked Le Corbusier to design a residential development in Geneva. Amongst the proposed buildings was an eleven-storey building that exhibited two features that became part of the Unité design: apartments that were L-shaped in cross-section, and had access corridors at every other level (Fig. 2). The development was not built.

\footnotetext{
1 For the full, and rather tortuous, story of the Domino House see 'The Domino Idea' by Eleanor Gregh in Oppositions Winter/ Spring 1979: 61-87.

2 This Parisian café, much frequented by artists and intellectuals, had a double-height space and window, with the kitchen at the back under a mezzanine.
}

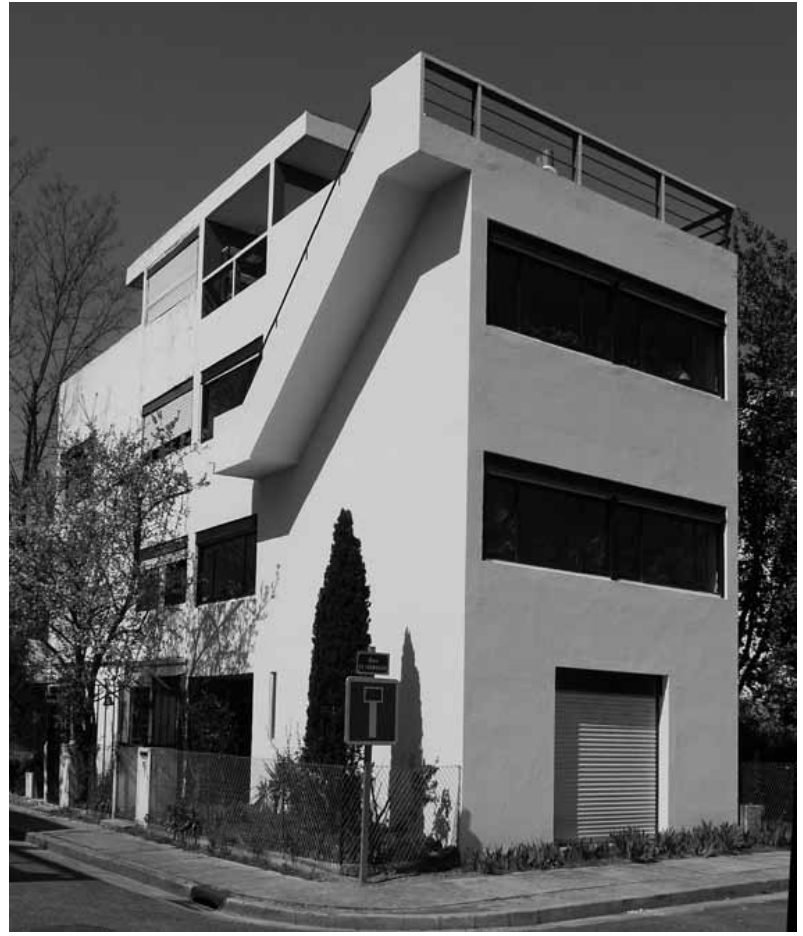

Fig. 1. Workers' housing at Pessac (photo by the author)

In 1933, Le Corbusier wrote, when promoting a four-storey housing scheme, 'How I pity the people who think they will be freer, better off in these little houses! They'll be hugging the ground while their neighbours in the four big buildings can gaze upon vast horizons and benefit from communal services' (Le Corbusier 1967: 295). He goes on to write 'The fundamental element of the city is THE DWELLING' (Le Corbusier 1967: 299).

In 1934, Le Corbusier signed an agreement to design a new district for Nemours in Algeria. Here he proposed eighteen individual blocks each of seventeen storeys. They were to be spaced out on a regular pattern with ample space between them. Here again the apartments had L-shaped cross-sections with access corridors at every other level (Fig. 2). The project was not built, as, according to one writer 'the problem was the large housing blocks which were probably frightening' (Archive... 2005: 7) .

Although Le Corbusier gave the impression that he was working on his own towards the Unité, there was a precedent in the Soviet Union. Architect Moisei Ginzburg was a member of the small but active artistic and intellectual avant-garde; he was also a founder member of the OSA (Organisation of Contemporary Architects). He designed something called a 'social

3 Commentary by Jean-Pierre Giordani (Archive... 2005). 


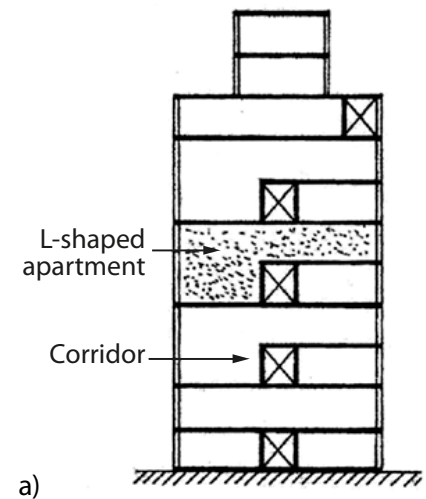

Fig. 2. Cross-section for proposals at Geneva (a) and Nemours (b) (created by the author) condenser'. The idea was to produce overlapping private and public spaces called collision zones, where different communities could interact - as Ginzburg put it 'the principal objective of constructivism ... is the definition of the Social Condenser of the age'. In 1928 Ginzburg got the chance to design one. Finished in 1932, it was called the Narkomfin building and was supposed to be a prototype of all subsequent state housing - in which it failed (Fig. 3).

This connection is not just speculative. Only occasionally mentioned in writings about the Unite d'Habitation, there are numerous links between Le Corbusier and Ginzburg, and between the Unité

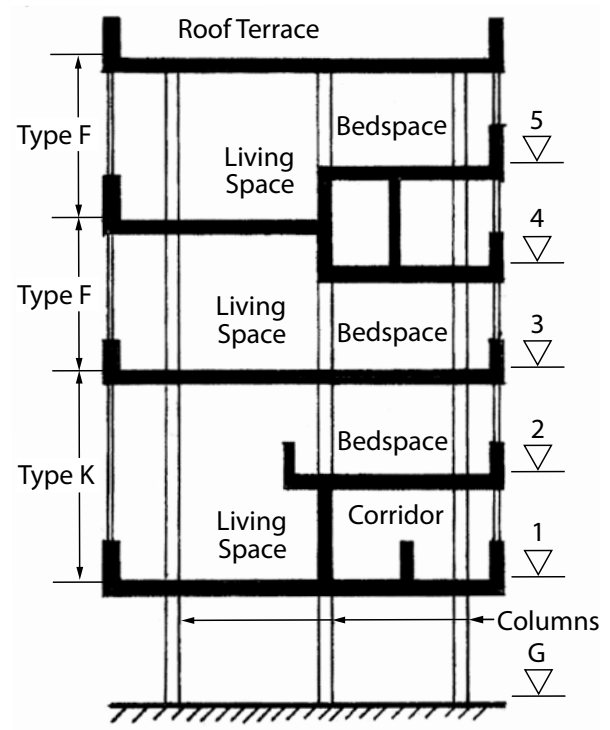

Fig. 3. Section through the Narkomfin social condenser (created by the author) and the Narkomfin building. Ginzburg knew about Le Corbusier's work from the early 1920s, and, as editor of Sovremennaia Arkhitektura, he promoted Le Corbusier's work from its first edition in 1926. In 1928, Le Corbusier went to Moscow, where he was already a celebrity in the architectural avantgarde. When he left, he took with him plans of the Narkomfin building.

\section{The beginnings of the Unité d'Habitation}

In July 1944 a provisional French government had been set up under General Charles de Gaulle. In November 1944, Raoul Dautry was appointed the Minister of Reconstruction and Urbanism. He asked Le Corbusier to make proposals for the housing of 14,000 new inhabitants in Saint-Gaudens, for a new industrial zone next to the port of La Rochelle, and to re-build the half of Saint-Dié that had been wantonly destroyed by the retreating German army. Each proposal included a number of large apartment blocks, typically housing 1600 residents. A combination of political problems and popular aversion to Le Corbusier's proposals meant that none went ahead (Archive... 2005) ${ }^{4}$.

The archival drawings for these projects mainly deal with town-planning issues; however there is an archival set of 137 drawings, dated 1944, and called Unités d'Habitation, recherches. According to Le Corbusier,

4 The clearest rejection was at Saint-Dié, where Le Corbusier's proposals were rejected by virtually all sections of the population; they wanted their town re-built as it was, which is what happened (see Commentary by Ivan Zaknic, Archive... 2005). 


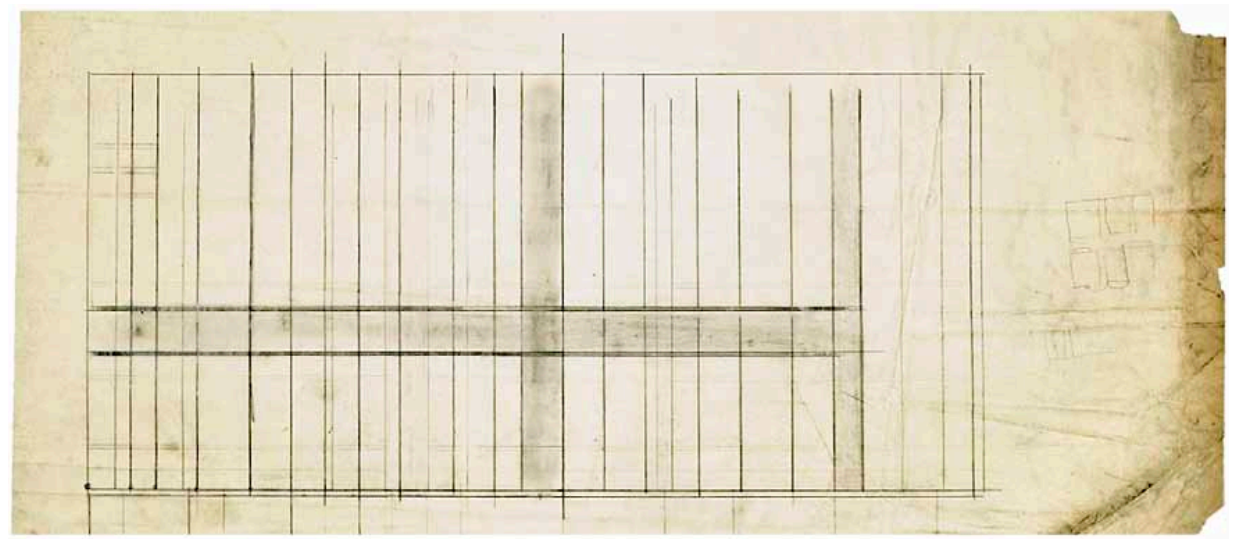

Fig. 4. Archive Drawing 30230 (source: Fondation Le Corbusier, @ FLC)

these were the culmination of years of research, writing, '... durant 43 années - une recherche vouée au logis des hommes' (during 43 years - research devoted to dwellings) (Le Corbusier 1950: 35). None of these drawings exhibits a convincing level of technical information (Fig. 4), seventy-seven of them being no more than unannotated free-hand sketches; so when Le Corbusier was called upon to design and build a Unité, his years of research had not really prepared him for the task, except in a very general conceptual way.

\section{The Unité becomes a reality}

On $27^{\text {th }}$ December 1945, the minister Raoul Dautry wrote to the municipal authorities in Marseilles saying 'I have decided that a Le Corbusier building will be constructed in your city. It is quite a challenging scheme, for it has to be built quickly, must contain a large number of apartments, must comply with all the latest health and safety regulations, must be of attractive design and in addition must contain some modern conveniences' (Le Corbusier 1950: 135) ${ }^{5}$.

Le Corbusier set up a special organisation called ATBAT (Atelier de Bâtisseurs - Builders Workshop), which was to design this Unité. Under the overall control of Le Corbusier, the leaders were architect André Wogenscky and engineer Vladimir Bodiansky. The idea was to produce innovative integrated designs -

\footnotetext{
5 Letter from Raoul Dautry to Jean Cristofol dated $27^{\text {th }}$ December 1945 (quoted in 'Le Corbusier: The Unité d'Habitation in Marseilles' by Jacques Sbriglio). Cristofol was the communist mayor of Marseilles. After World War II, communists filled many important posts in France, often promoting modern architecture (see 'Quand communisme municipal rimait avec laboratoire urbain (1944-1986)'. Journées d'études ler e 2 décembre 2009 - Université Paris 1). It is possible that Dautry, who was not a communist and who knew Le Corbusier, took this action hoping it might inconvenience his political rivals.
}

it was to be 'a synthesis of studies based on the crucial notion of a unified design concept' (Sbriglio 2004: 137).

The Unité d'Habitation was to be more than just an apartment block; it was to be une cité-jardin verticale - a vertical garden city. Called a 'unité d'habitation à grandeur conforme' - a 'large standard living unit' - the idea was to house about 1600 people, but with additional features such as shops, a hotel, a restaurant, a kindergarten, and communal sports, social and cultural facilities.

The concept for the building followed his research and his five points of architecture, together with the introduction of a new architectural 'point', the brise soleil - a fixed concrete sunshade. The sections of the apartments were based on the alternating L-shape, with balconies at either end. The shops, hotel and restaurant were on levels 7 and 8 , and on the roof there was to be a complex garden that contained the communal facilities. The apartments were to be accessed from rues intérieures at every second level, and the whole building was to be raised up on pilotis, and supported on a structural table that Le Corbusier called le sol artificiel - the artificial ground (Fig. 5).

Apart from the 'vertical garden city' innovation, there were to be others. The most radical was the idea that above the artificial ground there would be a structural steel framework - a type of 'bottle rack' into which individual apartments, prefabricated in a factory, would be slid into place. This idea was introduced by Jean Prouvé and enthusiastically taken up by Le Corbusier and Bodiansky (Jenkins 1993: 13). However, the framework could not be of steel as there was a material shortage, and the design team rather tardily realized the impracticality of sliding in whole units, so this innovation was dropped. But the idea of prefabrication was not dropped; it was applied to precast concrete units on the façade and to interior timber panels for the floor and wall construction. 
The main structure, built on a basic $4.19 \mathrm{~m} \times 4.19 \mathrm{~m}$ grid, became reinforced concrete. The vertical structure is a mixture of columns and walls, with the horizontal structure being a mixture of beam-supported slabs, and individual beams that support secondary floors of timber panels supported on steel beams. The artificial ground supports the whole of the upper structure on a

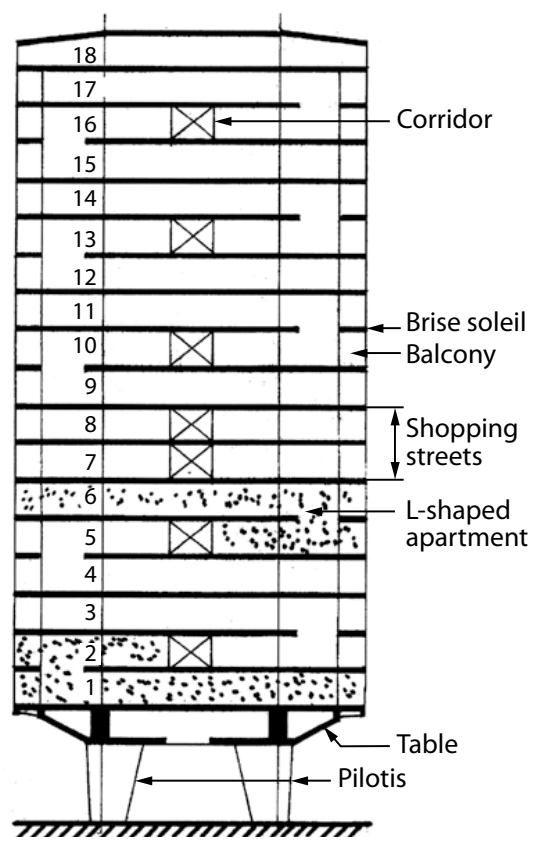

Fig. 5. Section showing the principal concepts (created by the author) grid of major transverse and longitudinal beams that carry the loads to the pilotis (Fig. 6). Longitudinally the pilotis are placed in pairs on every other grid at $8.38 \mathrm{~m}$ centres. Transversally the distance between the pilotis is $12.57 \mathrm{~m}$ (Fig. 6).

The system of heating uses ducted warm air. Although not an innovation as such, it was unusual in Europe at that time. Eight fans, fitted with heaters and humidifiers, supply the warm air. These are placed in pairs inside the artificial ground. Horizontal ducts, also within the artificial ground, distribute the warm air along the building, and these are connected to vertical ducts cast into the concrete walls. In each apartment, openings are made into the communal vertical ducts to supply its local duct system (Fig. 7).

The kitchens, bathrooms and WCs are all mechanically ventilated. Like the warm air system, local duct systems within each apartment are joined to the vertical ducts cast into the walls. Extract fans sited on the eighteenth level direct the stale air to a rooftop concrete 'chimney'.

There were other innovations as well. Le Corbusier wanted each apartment to be soundproof, so the internal partition walls consist of two independent timber-framed, plasterboard partitions, each sitting on independent timber and steel floor structures. The ends of the steel beams were to be mounted on individual blocks of lead, in an attempt to isolate them. a)

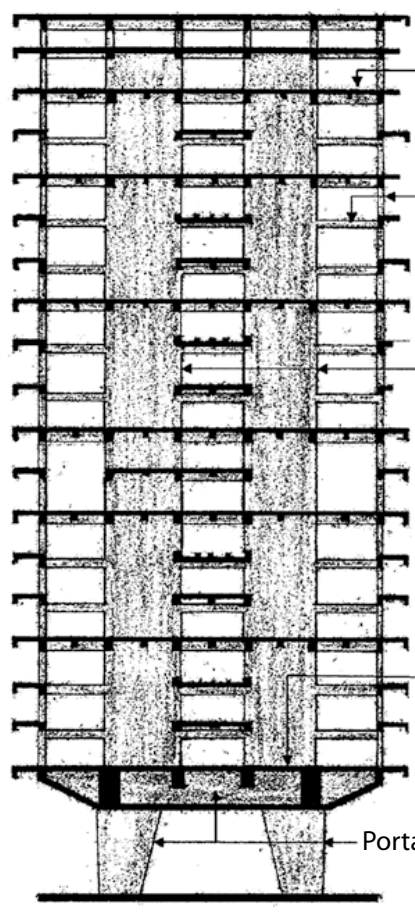

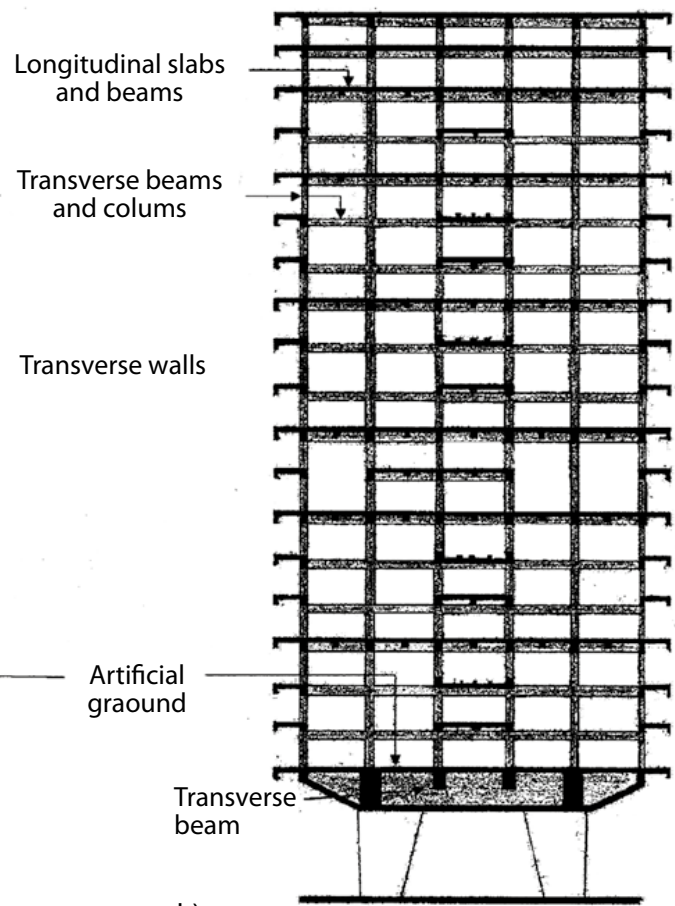

b)

Fig. 6. The concrete structure, on a line of pilotis (a), between pilotis (b) (created by the author) 
Since 1943, Le Corbusier had been working on a new measuring system; which he called Le Modulor (Le Corbusier 1961). The result was two series of numbers called the Red and Blue Series. Le Corbusier decided that he should use his discovery to dimension his new project. He claims that it was used for the 'General Plan and Section', and for 'An Apartment (plan and section)', as well in many other situations (Le Corbusier 1961: 131). A number of authors claim that use of the Modulor permitted the use of 'just fifteen measurements whose proportions are repeated in all the com- ponents of the building, which despite its huge size nevertheless remains on a human scale' (Sbriglio 2004: 143; Jenkins 1993: 9) 6 .

Detailed examination of the archive drawings shows this to be untrue (Fig. 8). It is interesting to note that even the main grid dimension of 4.19 metres is not a Modulor dimension.

6 "He [Le Corbusier] was proud to boast that in his Unité d'Habitation he only needed 15 standard measurements for the whole project, including dimensions of windows, doors, furniture etc." (The Modulor II 2012).

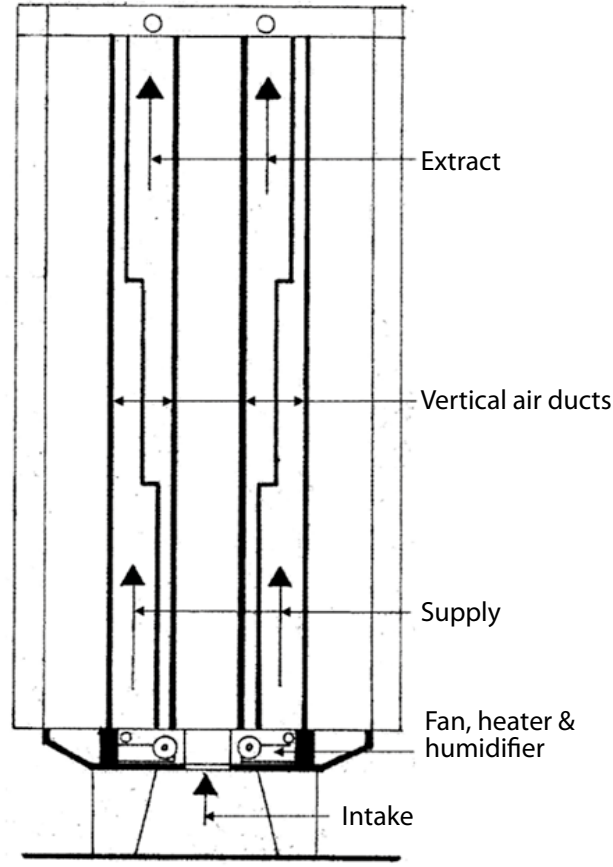

General scheme

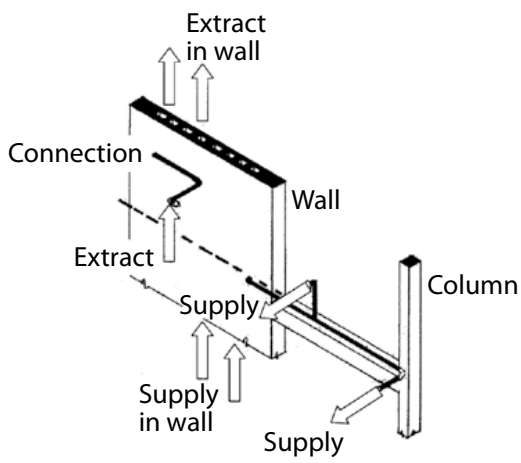

Apartment supply

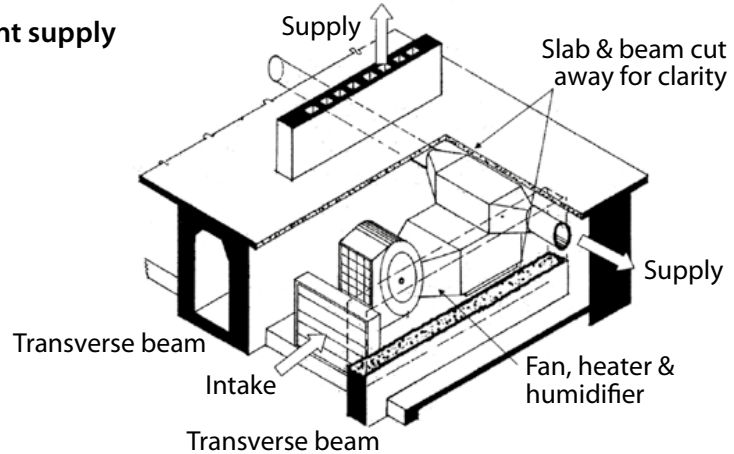

Equipment within the artificial ground

Fig. 7. The heating and extract schemes (created by the author)

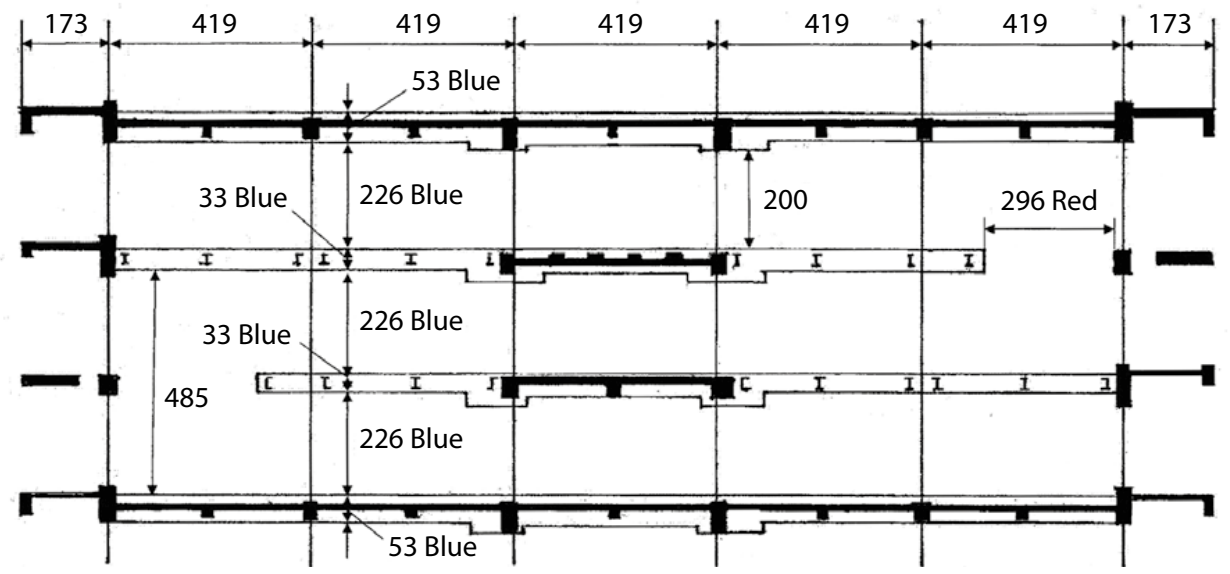

Fig. 8. Apartment cross-section showing Modulor (Red \& Blue) and non-Modulor dimensions (created by the author) 


\section{Construction}

The construction was started on $14^{\text {th }}$ October 1947 and the building was inaugurated on $14^{\text {th }}$ October 1952. There were 335 apartments of fifteen different layouts, although most of them, 199, were the standard $\mathrm{L}$-shaped apartments that were one $4.19 \mathrm{~m}$ bay wide. This gave an internal width of 3.66 metres.

The predicted construction period of one year had to be extended to five years, and the estimated cost of FRF $353,000,000$ rose to an estimated FRF 2,800,000,000, nearly eight times the estimate. No exact final cost has ever been published. Shortly after completion, in May 1954 , the state-owned building was sold off, and it is now a private condominium (Fig. 9).

\section{Critical assessment}

There are no fewer than three monographs written about the Unité d'Habitation in Marseilles (Le Corbusier 1950; Sbriglio 2004; Jenkins 1993) and books about modern architecture are unstinting in their praise. Here are just three typical examples:

Peter Blake in 1960 - '...his admirers watched the Marseilles building go up and hailed it as the ultimate revelation of architectural truth' (Blake 1960: 120).

William Curtis in 1986 - 'The Unité took the Catechism and gave the word invincible aesthetic form. And it did this in a rugged vocabulary ... wishing to give shape to a new, post-war state of mind'(Curtis 1986: 172).
Kenneth Frampton in 2001 - '... the Marseilles Unité still stands as a breathtakingly heroic monument to a particular moment in time. Never was the utopian modern project so convincingly and thoroughly realized as in this work ...' (Frampton 2001: 164).

But not everyone was so enthusiastic; here are three dissenting views:

Lewis Mumford in 1963 - 'Le Corbusier betrayed the human contents to produce a monumental aesthetic effect. The result is an egocentric extravagance ... (Mumford 1963: 81).

Peter Blake in 1974 - '...it is a spectacular hunk of sculpture - and a terrible hunk of living space... as an assemblage of dwelling units attuned to the need of twentieth-century living in plan, section, elevation, or general spatial organization, the Unité is a farce' (Blake 1974: 33) 7 .

Alexander Tzonis in 2001 - 'Le Corbusier's Unité points to the ecological devastation, the destruction of the natural landscape and the decline of the sense of joy of life' (Tzonis 2001: 160-163).

None of these critical voices delves very deeply into the problems that were caused by flaws in the design of the building. What needs to be borne in mind is that

7 This book, heavily criticising Modern Movement Architecture, is written by the same Peter Blake who had previously eulogised it.

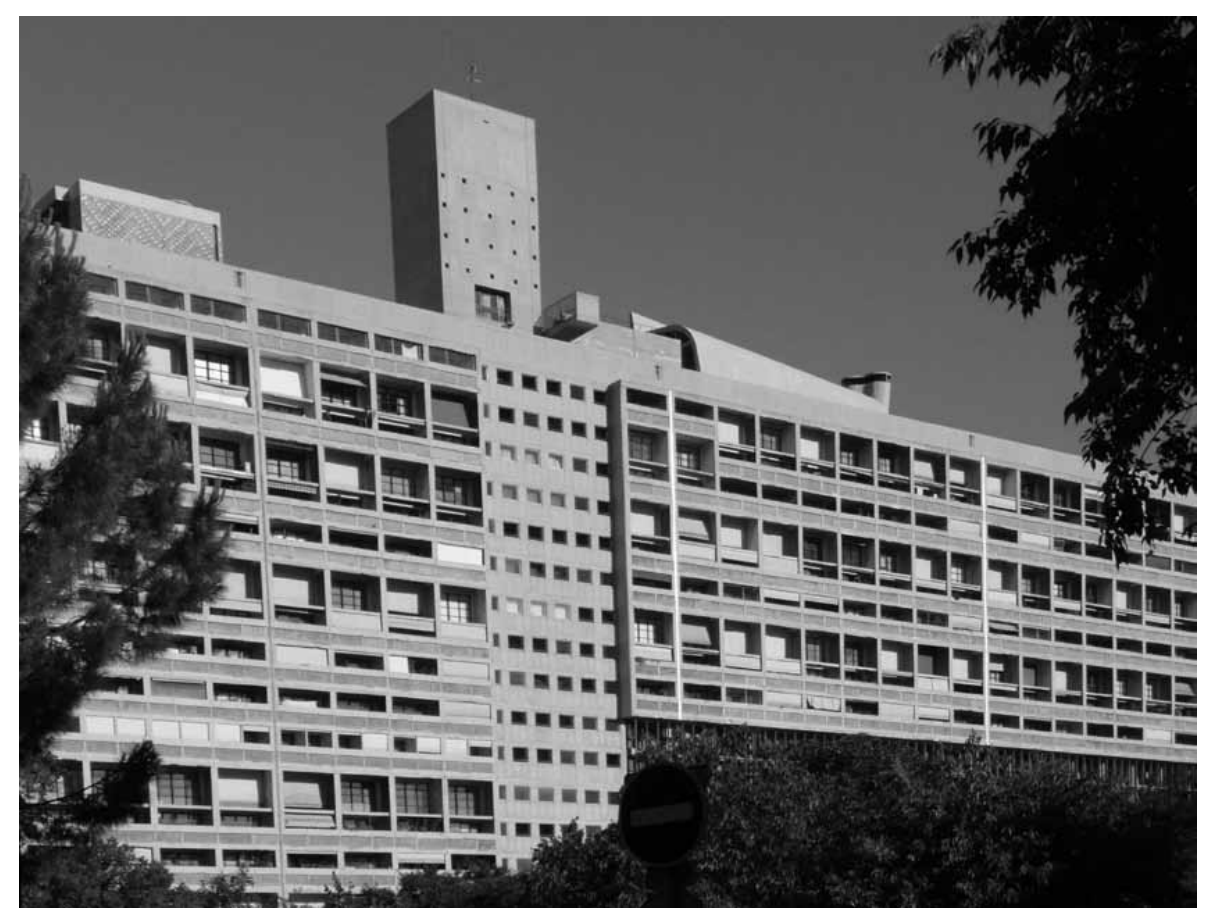

Fig. 9. The completed building (photo by the author) 
the Unité d'Habitation was not supposed to an iconic building, like for instance the Sydney Opera House, but to be a prototype for a building to be built in huge numbers all over the world. Even before the Marseilles commission, Le Corbusier had already made proposals for twenty-one such buildings.

The fact that it took five times longer to build than was anticipated, and that the final cost was at least eight times more than the initial estimate, is a clear indication of general failure ${ }^{8}$. This was not due to any innovative ideas or untried technology going astray - all the construction materials and techniques used were tried and tested in other hands. The failure was due to a total lack of understanding of sensible construction. One of the authors of the monographs notes 'Despite the gradual rationalisation of the design which Le Corbusier and Bodiansky had achieved subsequent to the preliminary scheme, the distance between theoretical intention and the practical realities of construction grew greater and greater' (author's use of bold text) (Jenkins 1993: 16). The existence of this 'distance' is reinforced by examination of the archive drawings that exhibit an almost amateurish lack of technical accomplishment.

\section{Building regulation non-compliance}

Building regulations are usually enshrined in the law of the land, and exist to provide the users with security and comfort - they are framed to ensure that current good practice is followed. Dautry's instruction that Le Corbusier's Unité was to 'comply with all the latest health and safety regulations' could be thought superfluous: after all buildings have to comply by law.

Earlier, in 1944, Le Corbusier had already informed Dautry that he would accept the commission on the condition that '...I don't have to comply with all the building regulations' (Sbriglio 2004: 134). Le Corbusier has already voiced, in 1933, his opposition to current building regulations when he wrote '.. the regulations become obsolete ... time has come to change the regulations' (Le Corbusier 1967: 53). When the foundation stone was laid in 1947, planning permission was yet to be granted (Sbriglio 2004: 163). In October 1948, and again in November, with the building already under construction, the current minister of construction, Eugène Claudius-Petit, received reports from the

\footnotetext{
8 The building is divided by expansion joints into four independent sections. In an attempt to control spiralling costs, one Minister of Reconstruction and Urbanism suggested that only some sections be built, which would have left the building even more dysfunctional.
}

Conseil Supérieur d'Hygiene Publique de France advising him that the project should be stopped, as it violated the public health regulations.

This was because the kitchens and dining rooms were nearly eight metres from a window; and the kitchen, bathroom, WC and the children's bedrooms, but above all the long access corridors, were entirely dependent on mechanical ventilation (Calfas 1949: 406). Moreover the floor to ceiling height of only $2.26 \mathrm{~m}$ was less than the legal minimum (Calfas 1949: 404) ${ }^{9}$. To resolve this 'problem', the minister summoned Le Corbusier and astonishingly told him 'You are free of all restrictions and above the law...' This was confirmed in July 1949 when the ministry issued a waiver exempting the project from the need for a building licence (Jenkins 1993: 17).

If the prototype did not comply with the building regulations, and needed a ministerial waiver to be legalised, what would have happened to the replicas? Assuming the regulations were not changed, as Le Corbusier wanted, either they would have to have been given a blanket waiver, thus making a mockery of the current building regulations, or each project would have been at risk.

\section{Conceptual flaws in the structure}

The structure of the building is conceptually flawed in numerous ways. The artificial ground is basically a transfer structure that serves no useful purpose other than complying, dogmatically, with Le Corbusier's first point of architecture. Furthermore, various design features augmented its expense. The columns were a complicated $U$-shape in section, with a tapering shape on elevation, thus needing complex formwork and reinforcement. To make matters worse, the bases of the columns were 'hinged' to the pile caps, by being supported in what were essentially 'buckets of sand.' This meant that the columns needed temporary support for stability until at least four columns had been built, together with the linking transverse and longitudinal beams.

Because the concrete walls contained ducts that required access from below, the transverse beams on the lines of the column had to be in pairs. To make the void within the artificial ground useable, all the transverse beams had to be built with a number of openings, again complicating the formwork and reinforcement.

The density of the columns above the artificial ground, on a $4.19 \times 4.19 \mathrm{~m}$ grid, is too high to reap the

\footnotetext{
9 Le Corbusier had been advocating a ceiling height of $2.20 \mathrm{~m}$ since 1933 (see Le Corbusier 1967: 52).
} 
economic benefits of reinforced concrete. The fact that there is a lack of repetition from floor to floor means that erecting the formwork for successive floors was slow and inefficient. It is usual to support the formwork for a slab from the floor below, but here in a number of locations there is no concrete slab directly below, so the supports for the formwork needed to be three storeys high. Again this was inefficient.

Probably the worst feature of the concrete structure is its transverse walls. Concrete walls are always expensive and slow to build because large areas of formwork are needed while - due to the reinforcement in the narrow walls - it is difficult to place the concrete. The presence of the fibro-cement duct formers, effectively narrowing the walls, creates further difficulties (see Fig. 7).

To carry the horizontal wind loads, the pairs of walls act as vertical cantilevers above the artificial ground. This load is shared between all the portals by the horizontally stiff concrete slab of the artificial ground. There are fifteen pairs of walls ${ }^{10}$, but a simple calculation shows that five sets of walls, three pairs at the expansion joints and one each at either end, would have been adequate.

Even when the concrete work was finished, the structure was still not complete: steel floor sub-structures at levels 2, 3, 5, 6, 10,11, 13, 14 and 16 had to be installed. This must have been slow and difficult, as the steel could not be craned in from above as the concrete slabs were in the way, so they would have been manhandled into position. Worse still was the fact that the steel was not fixed directly to the concrete, but was supposed to sit on lead pads within steel 'shoes.' These 'shoes' were to sit on the concrete beams. Here the problem would have been building tolerances. To overcome this it was proposed that the 'shoes' sat on beds of mortar whose thickness varied to give the correct level ${ }^{11}$. This would have meant time-consuming work under awkward access conditions ${ }^{12}$. In the event it appears that none of this happened, as the available construction photos show a variety of details, all of which can only be described as bodge-ups (e.g. Fig. 10).

Even with the all steel and concrete elements in place, the structure was still not complete. The flooring above the steel beams was of timber, and, in an attempt to use 'mass-production' these were prefabricated pane$1 s^{13}$, whereas carpenters would have found it far easier to use 'loose-fit' traditional joist construction.

\footnotetext{
10 See archive drawing no. 25352 (Archive... 2005).

11 See archive drawing no. 25938 (Archive... 2005).

12 Archive drawings nos. 25935, 25937 and 25938 show lead in a steel shoe bedded in mortar, whereas drawing no. 26679 shows the lead as a blob (Archive... 2005).

13 See archive drawing no. 25974 (Archive... 2005).
}

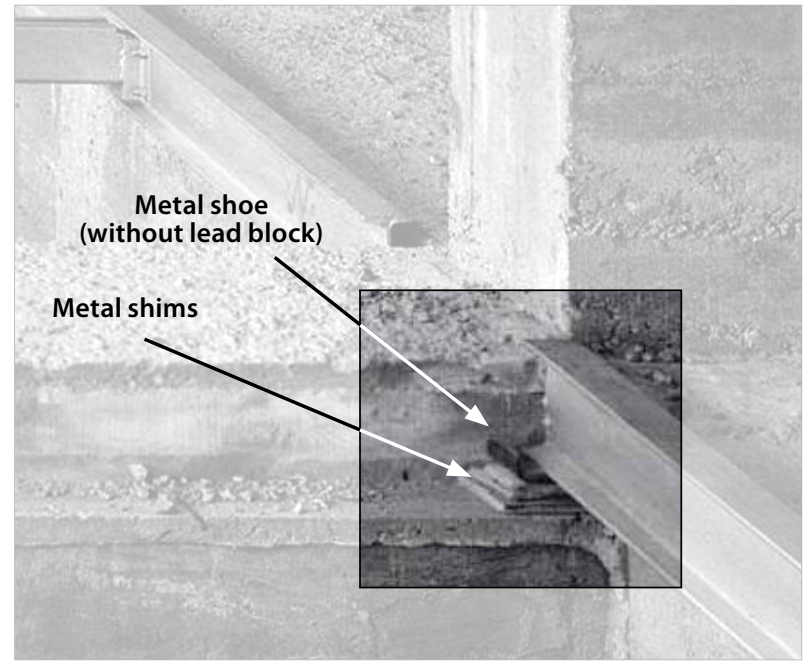

Fig. 10. Secondary steel beam connection - Photo L1 (13)121 (source: Fondation Le Corbusier, @ FLC)

\section{The external façade, balconies and mass-production}

As Le Corbusier thought mass-production was the way forward for buildings ${ }^{14}$, one could expect it to appear in his magnum opus. With the abandonment of the impractical 'bottle rack' idea, ABAT still thought some type of assembly line could be used, though quite how is unclear. Jenkins notes in his monograph that 'The assembly line ... was to turn out to be little more than empty rhetoric' (Jenkins 1996: 16). But precast concrete units were used, presumably to show that massproduction was part of the project. These units were mainly parts of the façade. The archive drawings show dozens of different units ${ }^{15}$; the balcony for a standard apartment has no fewer than twelve units, which are of eight different types. All these had to be combined with reinforced concrete in various ways to make up the balcony structure (Fig. 11).

From information shown on the drawings, it is possible to posit the following construction procedure:

1. Temporarily support the precast units (units numbered $1 \& 2$ ) that face the balcony edge beam.

2. Concrete the balcony slab, supporting beams and edge beam.

3. Place grille units on the edge beam (units numbered $34 \& 34$ ).

\footnotetext{
${ }^{14}$ In fact, Le Corbusier had no experience of mass-production, and had even gone to the extent, on occasions, of having things hand-made to look mass-produced (see Curtis 1986: 57).

${ }^{15}$ See archive drawings nos. 25090, 91, 95, 96 for example (Archive... 2005).
} 


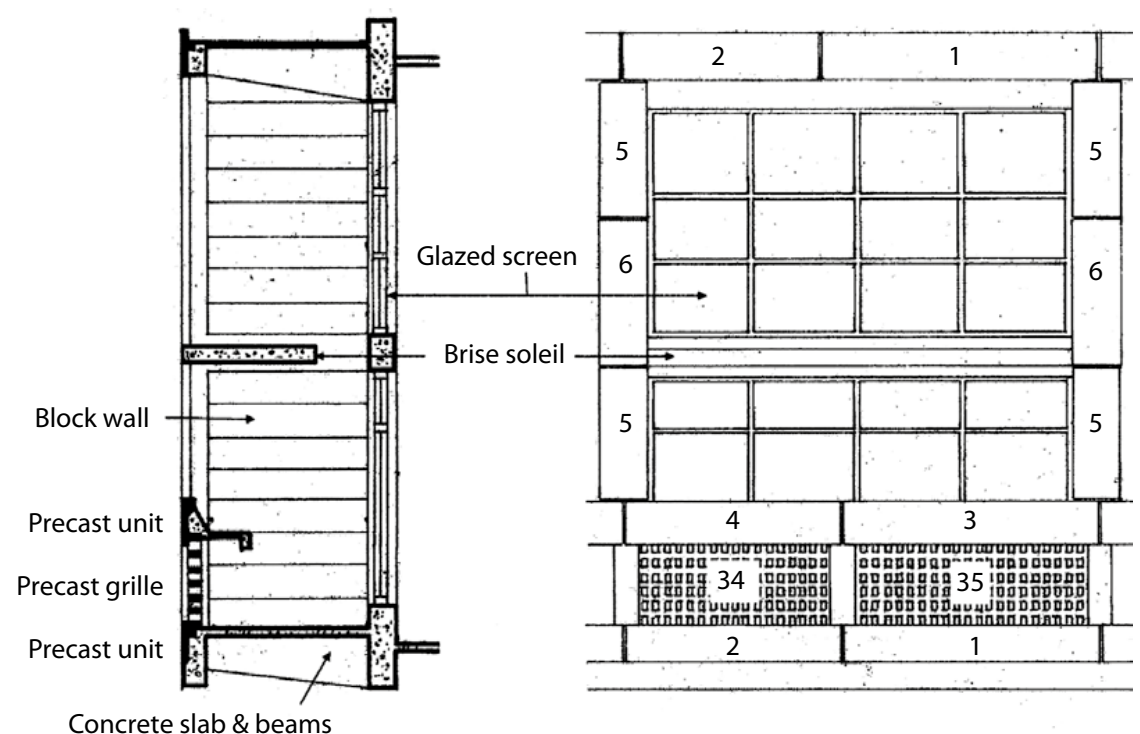

Fig. 11. Standard balcony construction, showing the original PC element numbers (created by the author)

4. Temporarily support the facing element for the top of the balustrade (units numbered $3 \& 4$ ).

5. Cast the beam along the top of the balustrade, at the same time cast the concrete shelf and supporting leg.

6. Install the vertical structural steel section between the balconies.

7. Temporarily support the precast units that form the outer face of the vertical concrete element (units numbered $5 \& 6$ ).

8. Cast the vertical element, thus embedding the structural steel section, and allow horizontal steel ties to protrude from the back of the column to be joined to the block wall.

9. Cast the brise soleil and its supporting beam.

10. Build the blockwork wall that separates the balconies.

It is easy to see that organising so many different types of precast units would present considerable problems. Even after all this, the building was still not weather tight, as the timber-framed glazed screens still had to be installed.

\section{Shortcomings of the heating system}

The main equipment is located within the artificial ground, but this is congested with single and twin transverse beams at every 4.19 metres - see Figure 7 . So the idea that the huge area available within the artificial ground could be used as a plant room is seriously compromised. There is insufficient space around the fans, and poor access means that removing and installing equipment is difficult. The ductwork is convo- luted, so installation and maintenance is also difficult. Furthermore, the convolution of the ductwork, not only inside the artificial ground but also inside the apartments, means that frictional air losses are high and require 'over-sized' fans, with consequent increases in initial and running costs.

\section{Poorly conceived sound insulation}

Le Corbusier thought he could control noise pollution by using various constructional devices. He proposed that some of the floor structures be mounted on blocks of lead, thinking that this would attenuate structureborne noise. Attenuation can be achieved when a soft material is used as the isolating medium, but lead is not soft - anyway these lead blocks were not installed (Fig. 10). Between apartments there were three layers of material. Two were layers of plasterboard fixed to timber framing, with a mineral wool backing; these formed the internal walls of the apartments. There was also a central thin block wall of gypsum ${ }^{16}$. This construction exhibits the common confusion of reducing noise transmission between spaces, where mass is needed, and achieving noise reduction within a space by 'soft' enclosing surfaces - mineral wool for example. As the lower glazing on each exterior face of the apartments was designed to open for its whole width, there was obviously a high possibility, especially in warm weather, of noise pollution from nearby apartments.

\footnotetext{
${ }^{16}$ Private correspondence with Architecte en Chef des Monuments Historiques.
} 


\section{Fire protection}

Fires in buildings are rare, but are a constant possibility; so building users expect a degree of protection. Fire protection is complex; however two basic ideas predominate, one of awareness and the other of escape. The awareness aspect not only means alarms, but also means that people in areas remote from the fire are given enough time to realise there is a fire. In practice this requires fireproof boundaries - floors and walls - which gives rise to the idea of boundaries fire-rated in hours. Having been protected by fireproof boundaries, the occupants then need fire-protected escape routes.

Most common building materials, with the exception of timber, are fireproof. But Le Corbusier, in his Complete Works, claimed 'fireproof timber' was used (Le Corbusier 1990: 189) - when a fire did occur, this turned out to be not the case (see below). In the case of the Unité, much of the structure is of reinforced concrete; however a number of floors and walls are of lightweight construction. In particular, separating floors between pairs of apartments are timber floors supported on steel beams with a plasterboard ceiling; this does not provide the required minimum fire rating of 1 hour. Within the apartments there is no effective fire separation between the different areas.

Normally the maximum distance to an escape route is considered to be between $9 \mathrm{~m}$ and $12 \mathrm{~m}$; in these apartments the maximum route is over $20 \mathrm{~m}$, and this is from a child's bedroom. There is no alternative means of escape, and the escape route ends by passing through the kitchen, the source of most domestic fires. As already noted, all the apartments are interconnected by a duct system, which was not fitted with dampers. Such dampers had been common practice since the mid-1920s for vertical ducts in apartment buildings (Fire dampers 1927: 213). This means

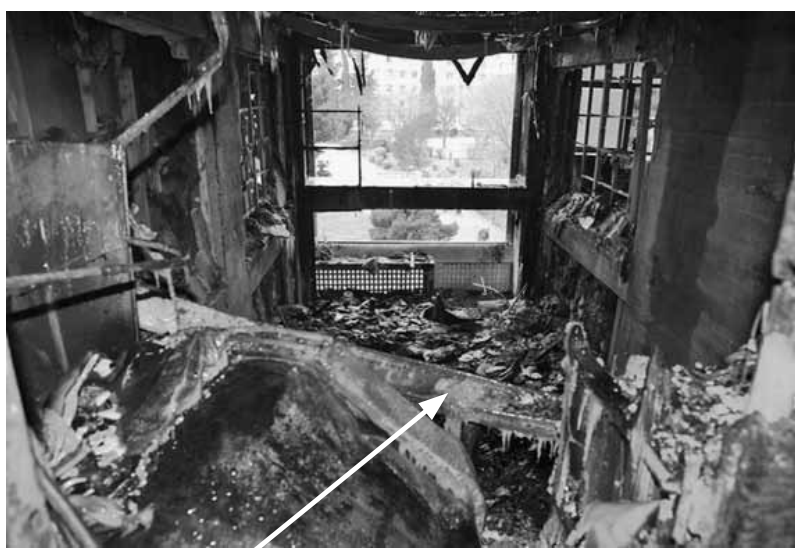

a) Part of collapsed fireproof floor that both smoke and fire have a route out of a burning apartment - and into other apartments connected by the duct system.

On $9^{\text {th }}$ February 2012, there was a disastrous fire at the Unité. It started on the first floor and eventually spread upwards. Eight apartments and four hotel rooms were destroyed, and a further thirty were badly damaged by smoke and water (Fig. 12). The whole building was evacuated, with only two-thirds of the apartments remaining inhabitable. According to the fire chief, the high combustibility of the floors and walls, and fire-spread through the ducts, contributed to the seriousness of the fire ${ }^{17}$. The spread of the fire was a direct consequence of the lack of dampers in the ducts, and the low fire-rating between apartments.

\section{Light and heat control}

Le Corbusier was very concerned that his apartments should benefit from natural light, and designed fullheight, full-width glazing at either end. Learning from experience in his own apartment that internal conditions become uncomfortable if the sun shines directly on this glazing (the greenhouse effect), Corbusier came up with the idea of fixed sunshades.

These were made of concrete and became famous, at least amongst architects, as brise soleils.

The idea is to block the high summer sun whilst allowing the low winter sun to enter.

The two illustrations of Figure 13a show the intended situation at noon in winter and summer. In summer, in the morning and evening, the sun's low-angled rays are powerful. This means that the Corbusian solution, using the brise soleil, is only applicable to south-facing

${ }^{17}$ So far no final report on the fire has been made available (see Incendie... 2012).

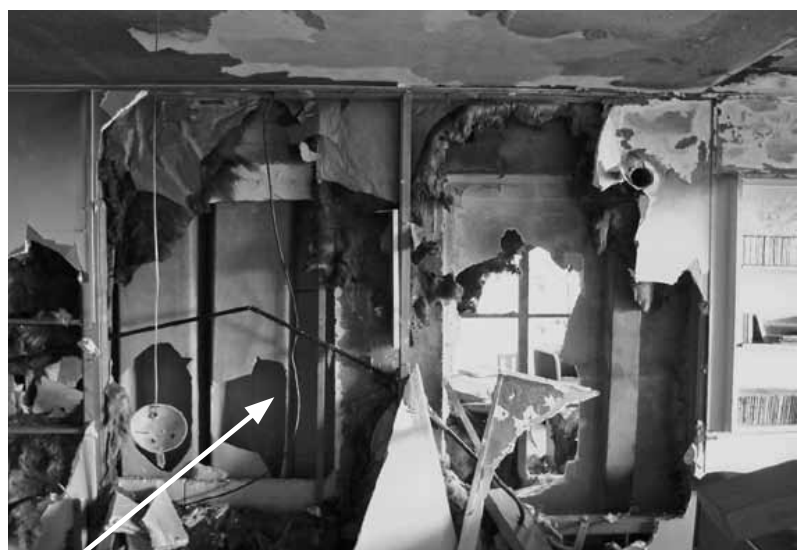

b) Damaged vertical ducts

Fig. 12. Fire damage (source: a) French fire service; b) Sud/Sud-Est Architectures) 

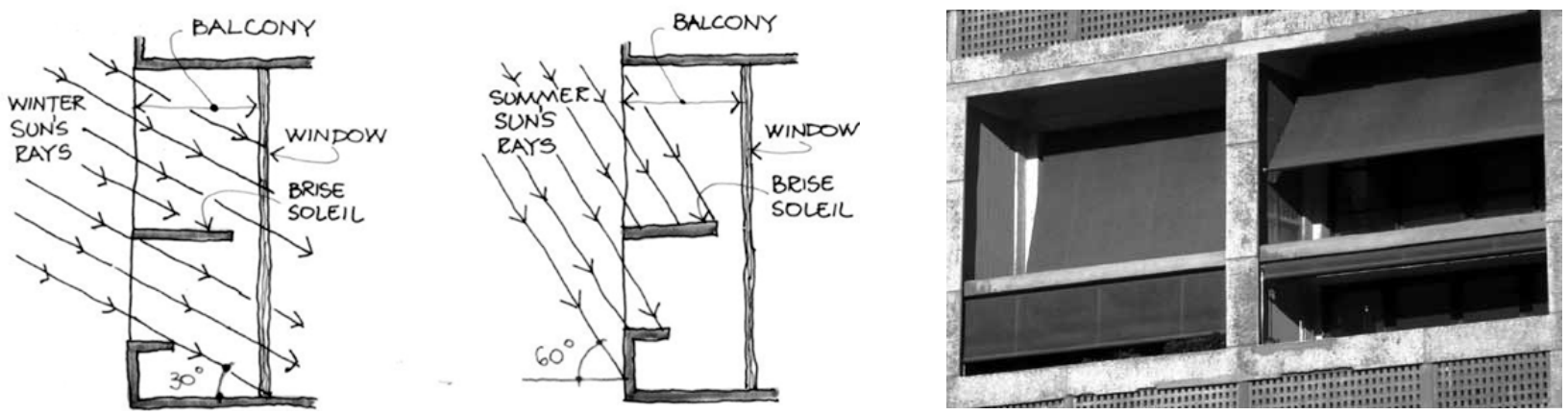

Fig. 13. The intended function of the brise soleil (a) in winter and summer, and the retrofitted blinds (b) (created by the author; photo by the author)

façades. At Marseilles, the long axis of the building is north-south, so the main elevations face east and west, meaning that in summer they catch the hot morning and evening sun - that is, the building's orientation is completely wrong for the brise soleils to function effectively. Consequently, almost all the residents installed oldfashioned roller blinds to protect themselves (Fig. 13b).

\section{Shopping streets, communal areas and the hotel}

The Unité not only has apartments, but there are shops, a hotel and a restaurant on levels 7 and 8 . On the roof there is a school, a running track, and various communal facilities. The idea of including such extras in a residential development is hardly new: for instance, the huge Dolphin Square development, built in London between 1935 and 1937, has these and more.

The extra features had mixed outcomes. The hotel has been in continuous operation from the outset but is strictly for Le Corbusier aficionados. One unhappy guest reported 'Without a doubt the worst hotel we've stayed in ... It may be of interest to arty architectural types ... It is difficult to put into words how dismal and depressing this hotel is' (Complete dump... 2012). The restaurant, with stunning views over the Mediterranean, is also still in use. The shops were a failure from the start. Not only was it difficult to service them seven storeys above the ground, but they could only attract trade from the residents, which was insufficient so they closed, as did the rooftop school. The other facilities continue in occasional use, but the concrete grimness of the roof 'garden' is hardly an attractive leisure destination.

\section{Conclusions}

Considering how poorly the Unité fulfilled its intended role as a prototype, it is perhaps surprising that four more unités were built, three in France and one in Germany. They were all considerably modified copies of the prototype; none tried to become vertical villages, they were just apartment blocks. Even this moderate success has to be set against the fact that, from 1945 up to his death in 1965, Le Corbusier produced schemes that included sixty-eight Unités. Only five were built, just over $7 \%$ of all those conceived.

Although, as this paper makes clear, the actual Unité d'Habitation at Marseilles was a failure as a prototype per se, it was conceptually - for architects at least - a brilliant success. The physical destruction wrought by World War II not only needed reconstruction, but in many places was also seen as an opportunity for comprehensive slum clearance. What rose in place of the bomb-damaged slums were often high-rise blocks of apartments, inspired directly by the Unite or indirectly by Le Corbusier's writings. As Phillip Powell, an architect with the London County Council, wrote in 1951, after visiting the almost complete Unité, '...the possibility of twenty- or thirtystorey blocks suggested by the Unité ... seems to be the only rational approach to high-density housing' (Murray, Osley 2009: 169). Consequently, all over the world, high-rise blocks of flats began to appear. But who was to live in them?

At the Unité it was never entirely clear what group or type of people was supposed to be housed, but as it was to be the prototype for housing worldwide, it could be surmised that it would suit Everyman. Le Corbusier's approach was rather different; here again he was a pioneer - he was designing for a type of person he thought should live in his buildings. There is no evidence that he was interested in ordinary people, he was designing for his idea of modern people - un homme type - a type of standard man that was a strange combination of monk, artist, athlete, worker and intellectual. As Professor Gans points out '... this individual turns out to be less like Everyman and more like Le Corbusier's carefully cultivated self-image' (Gans 2000: 20). She goes on to note of the Unite that 'as a private condominium it has housed those appreciative of its intentions' (Gans 2000: 113). Le Corbusier's lead in ignoring the desires of Everyman was followed 
faithfully but, unlike the Unité, the high-rise blocks that appeared were for social housing - tenants without choice.

The social problems that the Corbusian solution caused are now well known. In the early 1980s, Professor Alice Coleman led a research team to find out what architectural features are detrimental to social housing (Coleman 1985). Between 1979 and 1984, they surveyed 4,099 blocks of apartments and 4,172 houses (Coleman 1985: 2). Their results, supported by the evidence, were published in Utopia on Trial: Vision and Reality in Planned Housing, 1985. This disturbing book condemned every Corbusian feature: high-rise structure, single entrance to the building, no external private space, the corridors with apartments on both sides, approach paths winding through greenery, massive slab blocks, blocks on stilts (pilotis), on site facilities, open plan, L-shaped apartments, and blank end walls.

Gradually these high-rise estates attracted pejorative names, such as 'sink estates' in Great Britain or 'the projects' in the United States. In France, these estates were known as HLM, the acronym for Habitation à Loyer Modéré (Moderate Rent Housing). HLM quickly passed into colloquial French to mean bad or low quality. This has led to a huge number of these buildings being demolished. The most notable was the demolition, starting in 1972, of the thirty-three eleven-storey blocks that made up the Pruitt-Igoe estate in St. Louis, USA. But while Corbusian high-rise blocks for social housing continue to be demolished, the high-rise condominium, such as London's Barbican estate '... is a well-loved and sought-after development for many reasons. Its brutalist Fifties-style, inspired by such architects as Le Corbusier ...' (Estate agents'... 2012).

The Unité d'Habitation, designed by Le Corbusier and built in Marseilles, can be seen as the building that changed the course of twentieth-century architecture. It inspired a new generation of architects to think that rejection of what is often simplistically called traditional architecture was correct, and that Le Corbusier was showing the way forward. As this new architecture proved vastly unpopular with the majority of the general public, this has led to polarised views on much of post-1945 architecture. This polarisation continues today with, for instance, the strongly divergent views held about the Shard of Glass, an enormous tower recently completed in London.

\section{References}

Almanach de l'Architecture Moderne. 1926. Paris

Archive drawings and commentaries. 2005 codex images/ Remixpoint.inc. 2005. Fondation Le Corbusier.

Blake, P. 1960. Le Corbusier: Architecture \& form. London: Pelican Books.
Blake, P. 1974. Form follows fiasco. Boston: Little, Brown \& Co.

Calfas, P. 1949. Le Bâtiment dit 'Unité d'Habitation' de L’Architecte Le Corbusier, a Marseille, Le Genie Civil 1949: $1^{\mathrm{er}}$ novembre.

Coleman, A. 1985. Utopia on Trial. London: Hilary Shipman.

Complete dump - more like a prison than a hotel [online], [cited 21 July 2012]. Available from Internet: http://www. tripadvisor.com.br/ShowUserReviews-g187253-d195833r12408924-Hotel_le_Corbusier-Marseille_Bouches_du_ Rhone_Provence.html\#REVIEWS

Curtis, W. J. R. 1986. Le Corbusier: Ideas and forms. London: Phaidon Press.

Estate agents' advertisement [online], [cited 24 April 2012]. Available from Internet: http://www.homesandproperty. co.uk/1828522

Fire dampers. 1927. National Fire Protection Association Annual report.

Frampton, K. 2001. Le Corbusier. London: Thames \& Hudson.

Gans, D. 2000. The Le Corbusier Guide. New York: Princeton Architectural Press.

Gregh, E. 1979. The domino idea. Winter/Spring Oppositions $15 / 16$.

Incendie maîtrisé à la Cité radieuse Le Corbusier de Marseille [online], [cited 21 July 2012]. Available from Internet: http:// tempsreel.nouvelobs.com/societe/20120210.OBS1027/incendie-maitrise-a-la-cite-radieuse-le-corbusier-de-marseille.html

Jenkins, D. 1993. Unité d'Habitation Marseilles. London: Phaidon Press.

Le Corbusier. 1927. Towards a new architecture. Translated by Fredrick Etchells. The Architectural Press.

Le Corbusier. 1950. L'Unité d'Habitation de Marseille, Le Point 38: Novembre.

Le Corbusier. 1961. Le Modulor. Translated by Peter de Francia \& Anna Bostock. London: Faber \& Faber.

Le Corbusier. 1967. The radiant city. Faber \& Faber.

Le Corbusier. 1990. The complete works Vol. 4 1938-46. Birkhäuser Architecture.

Mumford, L. 1963. The highway and the city. New York: Harcourt Brace.

Murray, I.; Osley, J. 2009. Le Corbusier and Britain: An anthology. Routledge.

Sbriglio, J. 2004. The Unité d'Habitation in Marseilles. Basel: Birkhäuser.

The Modulor II [online], [cited 20 July 2012]. Available from Internet: http://paulscottinfo.ipage.com/place/pm16/pm16. html\#anchor5

Tzonis, A. 2001. Le Corbusier: The poetics of machine and metaphor. London: Thames \& Hudson.

\section{MALCOLM MILLAIS}

Born London 1940. Qualified as a Chartered Structural Engineer in 1966. PhD awarded by London University in 1976. Design structural engineer for numerous building and civil projects, ranging from small works to major projects like the Kuwait State Mosque. Author of 'Building Structures: from concepts to design' published in 1997, with a second edition in 2005. Author of 'Exploding the Myths of Modern Architecture', published in 2009. 